\title{
Formalising credit markets? The entrance of English joint-stock banks
}

Book or Report Section

Accepted Version

Newton, L. and Barnes, V. (2018) Formalising credit markets? The entrance of English joint-stock banks. In: Coffman, D.'M., Lorandin, C. and Lorenzini, M. (eds.) Financing in Europe. The evolution, coexistence, and complementarity of credit typologies from the Middle ages to the 19th century. Palgrave Studies in the History of Finance. Palgrave Macmillan, Basingstoke. Available at http://centaur.reading.ac.uk/70079/

It is advisable to refer to the publisher's version if you intend to cite from the work. See Guidance on citing.

Publisher: Palgrave Macmillan

All outputs in CentAUR are protected by Intellectual Property Rights law, including copyright law. Copyright and IPR is retained by the creators or other copyright holders. Terms and conditions for use of this material are defined in the End User Agreement. 


\section{www.reading.ac.uk/centaur}

\section{CentAUR}

Central Archive at the University of Reading

Reading's research outputs online 


\title{
Formalising credit markets? The entrance of English joint-stock banks
}

\author{
Victoria Barnes and Lucy Newton ${ }^{1}$
}

\section{Introduction}

This chapter explores the entrance of joint-stock banks into the English financial markets in the first half of the nineteenth century. Following the financial crisis of $1825 / 6$, legislation allowed joint-stock banks to form with an unlimited number of owners and to operate alongside private banks. Private banks were limited to just six partners and tended to grow out from excess capital which was gained from land, industrial and commercial activity (Pressnell 1956). Joint-stock banks, in contrast, possessed an identity that was not tied to a small body of owners. With an unlimited number of proprietors, these banks were not, like private banks, solely based on the personalities of their owners and close family or interpersonal ties (Black 2003, 1996). Instead, joint-stock banks were governed by a tiered structure of professional managers and were supervised by a board of directors elected from the shareholding. These banks existed as one of the first forerunners to the modern corporation (Gower 1979: 39).

Joint-stock banking companies constituted, first and foremost, a set of banks which specialised in financial activity exclusively. As each bank acted as an intermediary between depositors and borrowers, it coordinated the supply of credit in the local market. This chapter examines (1) the extent to which this financial 
institution represented a step towards a corporate entity or new organisational form, (2) whether these banks remained informal and individual in their approaches to lending or if they began to apply formal credit-scoring mechanisms. We, therefore, analyse the impact of the change in organisational form on the methods and criteria used to assess creditworthiness. This chapter explores lending policies to determine whether these financial institutions participated in a 'formalisation' of credit markets in which banks ceased engaging in a personal or character-based assessment of applicants in favour of an objective, standardised or consistent style of evaluation. In order to do so, this chapter utilises minute books from the meetings of Boards of Directors. In particular, it selects five joint-stock banks formed in the first half of the nineteenth century to provide a detailed analysis of their management and lending policy. These are the Huddersfield Banking Company, the Nottingham and Nottinghamshire Banking Company, the Liverpool Union Bank, the Bilston District Banking Company and the Sheffield and Rotherham Banking Company.

This chapter contains five parts and the structure is as follows. It begins by exploring the changes in organisational form in the transition from private to jointstock banking over the course of the first three sections. It distinguishes between legal and non-legal attributes, with the most important facet being the structure of governance and the management of the organisation. The final two sections examine how these banks undertook lending activities, as well as the criteria, methods and mechanisms banks used to assess creditworthiness. It investigates the extent to which credit was given with or without security and how central the bank's personal knowledge of the applicant was in decision-making. 


\section{Organisational form}

The modern private company or corporation possesses three key legal characteristics: a separate legal personality, limited liability, and freely transferable shares. More often than not, this definition is thought to encompass the presence of a managerial hierarchy and it is assumed that a corporation will also possess such a system of governance, in addition to the three legal attributes (Harris 2000: 23). Here, we distinguish between the term 'corporation' which has a strict legal meaning and the broader non-legal points often thought to be suggested by it. To describe the management and governance structures as well legal characteristics, 'organisational form' will be used instead as a catch-all phrase.

Under English law, private banks were partnerships not corporations. These banks were restricted to just six owners, called partners, who were often both owners and managers and, without limited liability, liable to the whole extent of their fortune. It is, however, more difficult to classify joint-stock banks in this organisational matrix of corporation versus partnership (Collins 1994). English statute law has historically restrained the use of the corporate form as defined by limited liability and also the use of a separate legal personality (DuBois 1938).

The two were, of course, related. The use of separate legal personality allowed a group of individuals to be known in law by a collective name rather than each individual's name. With a separate legal personality, corporations would be known as an 'it' and an independent artefact of its ownership, rather than a 'they' which suggested it served as a group of individuals (Ireland 1996). If a corporation had a personality which was separated by law from that if its owners, then it could hold property and make contracts in its own name. A barrier or dividing line, therefore, 
existed between the corporation's assets and the owner's assets. In other words, the use of separate legal personality made limited liability permissible. In the event of failure, this would allow investors to risk only the sum that they had paid for the share rather than their whole fortune.

A company could have a separate legal personality without limited liability but this was unusual. This privilege alone, despite its lack of immediate appeal, was, in truth, fairly sought after in the nineteenth century and given away by legislators more often than limited liability. This can be seen in the insurance industry, for instance (Pearson 2004: 238-9). A separate personality by itself also had a more pragmatic use in the sense that without it, litigation could often be cumbersome. Suing a single name, rather than all of its owners, was understandably much less complicated.

The legislation that permitted the promotion of joint-stock banks denied these firms the powers of a corporation. The Banking Co-partnership Act 1826 lifted the six partner restriction for banks based sixty-five miles outside of London. Yet, under the Banking Co-partnership Act 1826, none was permitted to use limited liability. Allowing the adoption of limited liability would have encroached upon the bargain struck between the English government and the Bank of England, which possessed a full set of corporate attributes. Considerable confusion surrounded the notion of unlimited liability and how statutory interpretation might be applied in practice or in a court of law (Gilbart 1828: 56-8). Even so, it was clear that the owners in joint-stock banks underwrote all debts. In other words, these were institutions with unlimited liability and thus every shareholder, including the bank directors, was liable for all of the bank's debts. Instead of limited liability, legislators gave joint-stock banks a form of separate legal personality. 
This took in the form of a named public officer rather than the usual format of the actual company name. Joint-stock banks would, therefore, appoint a public officer to be sued and to sue in. For this reason, contemporaries dubbed them 'quasicorporations' and they held a middle ground between the corporation and partnership (Cottrell 1980: 42; Wordsworth 1842: 41). The 1826 Act was extended to London in 1833 when new legislation clarified that banks with more than six partners were permitted by common-law to form inside London. However, these London banks were not permitted to issue bank notes, unlike the joint-stock banks in the provinces, again in order to protect the Bank of England's privileges. Also, in contrast to the legislation passed in 1826, the 1833 Act did not allow London joint-stock banks to have a function of a public officer. Thus, the Bank of England sought to protect its monopoly on the corporate form in London more than it had done so in the provinces (Grossman 2010: 179).

The result of this legislation was that joint-stock banks were denied the corporate rights of limited liability or a legal personality. In this sense, they were not very different to a partnership or a private bank. New banks that used the joint-stock form were still ultimately bound by a set of human characteristics and personal guarantees. Joint-stock banks in the provinces existed as a public officer, a person and a name not an abstract inhuman corporate entity. Their debts and liability were not a separate matter either. It could not be removed or extracted from the concept of ownership. In comparison to both limited liability and legal personality, the ability to transfer shares was governed by the firm's articles of association. These internal mechanisms existed to regulate corporate governance and set boundaries. 


\section{Ownership}

The company's articles of association constituted a contract between owners which would set out the rules and bind these shareholders. Provisions in them generally set out that shares could be transferred upon meeting certain conditions, such as the meeting of the directors or at an Annual General Meeting of shareholders (Gower 1953: 535-6). Unlike legislation which placed impositions or barriers across all companies, banks could take individual approaches to such matters.

The contracts and articles of association (also known as deeds of settlements) for joint-stock banks became standardised to the extent that most followed a similar or typical pattern. For joint-stock banks, the transfer of ownership would generally take place after approval at the board of directors' meetings. It was important to control who owned shares in the bank, due to unlimited liability and also the need to signal trust and confidence in the bank through possessing wealthy and reliable shareholders. Turner (2014) has persuasively argued that the wealth of individuals and their activity in a regime of unlimited liability ensured that banks remained stable. His empirical study of the shareholder registers has shown that low-wealth individuals rarely became shareholders (Turner 2009a).

While joint-stock banks amassed a wide range of shareholders who invested in what was often thought to be small denomination shares (Turner 2009b), private banks were limited to a maximum of six partners. With such a low level of owners, partners would have to invest large amounts of capital for the bank to begin to lend or finance industrial activity. For these banks, ownership was not sold on the open market but entrance into such concerns was often bound by mutual ties such as familial or close commercial relationships (Pressnell 1956: ch. 3). With such a small 
number of partners involved, they would be well-known to one another on a close personal basis.

Owners in joint-stock banks were simply not as familiar. This should not be taken to mean that owners were either foreign or complete unknowns. It simply meant that, with over 1,000 owners in some cases, it cannot be expected that all could know each other in the same intimate or personal fashion that six people in a private bank could know each other. The connection between owners in joint-stock banks was local or neighbourly, if not familial or intimate. The vast majority hailed from the locality or adjacent counties (Newton 1997). In this sense, shareholders would be known in a wider community context. This was far removed from the relationships between family members or between those who knew each other intimately, as existed in private banks. Yet, shareholding in a joint-stock bank was rarely similar to that of a modern corporation and distant capitalists from London did not invest in a serious manner in provincial joint-stock banks (Michie 1981: 61-2).

The ordinary local shareholders, bound together by the risk of unlimited liability, possessed a small number of rights or privileges. Yet, the most significant right of all was not to inspect books, or hold management to account at a meeting, but to be a formal part of the decision-making process. This was a right granted to shareholders who became directors, through an election by fellow shareholders. This position did not exist in private banking. Indeed, with this role, we can observe the development of new governance regimes.

\section{Decision-making process}

A small number of shareholders were elected and became directors. What did directors do in this period? As a collective, they joined either a court or board of 
directors. First and foremost, their position would not be understood in the same way it exists today. Directors rarely held salaried positions and remuneration was often commemorative rather than payment for the hours spent at the bank. The directors of the Huddersfield Banking Company, established in 1827, 'received no fees until as late as the 1890s, and in the records of the Bradford Banking Company [founded in the same year] there is no trace of remuneration until 1864' (Crick and Wadsworth 1936: 204-5). Directors would, therefore, gather on occasion in an unpaid capacity. Their role would be to supervise, discuss matters and consult with the bank manager, and examine the books. In short, they had the power to question or deliberate and consult on wider policy and strategy. In this arrangement, they could delegate matters to employees or servants, as they were known in this period (Deakin and Wilkinson 2005).

Table 1: First Directors of the Liverpool Union Banking Company, established 1835

\begin{tabular}{|l|l|l|l|}
\hline Pim & $\begin{array}{l}\text { Joseph } \\
\text { Robinson }\end{array}$ & Liverpool & Merchant \\
\hline Miller & John & Liverpool & Merchant \\
\hline Allport & Benjamin & Liverpool & Merchant \\
\hline Rodick & Thomas & Liverpool & Merchant \\
\hline Firth & Thomas & Northwich & Banker \\
\hline Holmes & Henry & Liverpool & Merchant \\
\hline Heyworth & Lawrence & Liverpool & Merchant \\
\hline
\end{tabular}

Source: Lloyds Bank Group Archives [LBGA]: Liverpool Union Banking Company

[LUBC], Board of Directors Minutes [BDM], Book No. 093, 16 ${ }^{\text {th }}$ April 1835.

With large numbers of branches and transactions, decision-making took place simultaneously at a number of different locations. It meant that even convening with 
management and overseeing transactions from the bank as a whole could become a demanding task. Some directors found this to be incompatible with running their own businesses. The Liverpool Union Banking Company, as shown in Table 12.1, was established in 1835 by a group of merchants from the city to service the accounts of other Liverpool merchants (Sayers 1957: 92-3). One of the directors of the Liverpool Union Banking Company resigned in 1837 due to "the increasing attention required at home and the inconvenience of leaving his business periodically'. ${ }^{2}$ The bank formed in a busy, thriving commercial centre. By the end of 1836, it had 358 shareholders; had allotted 25,735 shares; had a paid-up capital of $£ 257,350$; a profit after deductions of $£ 13,646$; a profit after payment of dividends of $£ 3,352$; and a reserve fund of $£ 55,703 .{ }^{3}$ All in all, sitting on a board could be taxing even as a part-time commitment. Aside from six merchants, Thomas Firth was the seventh member of the original board of directors and was a professional banker.

Firth was also a salt merchant but had established Thomas and Sons as a private bank in Northwich in 1817, an institution that was eventually taken over by Parr's Bank of Warrington in 1865 (Dawes and Ward-Perkins 2000: 431). In taking a place on the board of the Liverpool Union Banking Company he could offer his expertise, which was clearly beneficial to the joint-stock bank. On the other hand, it is not possible to discern the benefit that Firth or his private bank gained from his position on the Liverpool Union's Board. Presumably, the two banks did not compete for the same customers.

Acting as a director would not mean working in the bank on a day-to-day basis - many, like Firth, had their own business to run. The role meant that they had more rights and involvement than the ordinary shareholder. The board in Bilston District Banking Company provides another good example of directors who did not 
consider themselves professional bankers but rather, identified as having other occupations. The bank was founded in 1836 in the town of Bilston, in the West Midlands, a region of coal mining, iron manufacture, and metal-working. The founders of the bank stipulated that all directors must hold 50 shares in the bank and live within seven miles of Bilston.

As can be seen in Table 2, the founding directors of Bilston District Banking Company were local industrialists. The bank moved to Wolverhampton (approximately 3 miles away) in 1843 and remained independent until 1899 (Orbell and Turton 2001: 170). It appears that these directors did not identify their occupation as banker or bank director and thought that their other positions in other industries constituted their main activity. In lieu of a constant or full-time presence at the bank, directors simply delegated many of the tasks associated with managing the firm to individuals who did see the role as their professional activity.

Table 2: First Directors of the Bilston District Banking Company, established 1836

\begin{tabular}{|l|l|l|l|}
\hline Perry & Thomas & Bilston & Iron merchant \\
\hline Round & John & Brierly Sedgley & Coal master \\
\hline Sparrow & William & Hanbury & Ironmaster \\
\hline Bowen & William & Bilston & Brass founder \\
\hline Walker & Joseph & Wolverhampton & Factor \\
\hline Crowley & John & Wolverhampton & Carrier \\
\hline
\end{tabular}

Source: RBS Group Archives [RBSGA]: Bilston District Banking Company

[BDBC], BDM, 11342, $10^{\text {th }}$ June 1836.

On the whole, directors met fairly infrequently. The irregularity of board meetings should not be taken to suggest that the board had no involvement in decision-making 
or that all tasks would be deputised. Certainly, substantial loan applications would be reserved for discussion and approval at board level and as this decision warranted the director's consent. The simple reason for discussion was that the extension of large volumes of credit, or, to be more precise, the failure to repay large unsecured amounts of credit, could destabilise the bank. Risky advances, therefore, needed more thought, deliberation, and consultation with the directors as representatives of the shareholders. There were undoubtedly instances where shareholders and the board felt that decisions may have been made by managers without their agreement. Directors were also more explicit when managers did not listen or adhere to their policies.

One such example is in the Liverpool Union Banking Company. The directors stated that no new accounts were to be opened by the manager unless cash were paid into them. The general manager, Mr. Lister, was 'not only in written defiance of such a resolution' but the board thought 'deserving of severe reprobation and not to be repeated'. Notwithstanding such stern words, Lister continued in the post for thirtynine years. Lister managed the Liverpool Union from its foundation. In his capacity as general manager, he also developed a great reputation for his expertise on joint-stock banking. Other bank managers sought his advice (Sayers 1957: 52). His defiance does not appear to have affected his career. Banks did not yet have a position of managing director and those who used the term 'manager' held the position of general manager and were not part of the board.

This example of managerial disobedience and reluctance to consult or obey the directors' instructions was, by no means, an isolated or rare incident. In other cases, managers and agents 'persistently made advances contrary to the Board's instruction' (Sayers 1957: 77). It was clear that the selection of managers, as well as a good relationship between local managers and bank directors, was crucial in ensuring 
that a balance was struck between different interest groups and that undue risk was not taken when advancing money to customers (Sayers 1957: 77-81).

Table 3: First Directors of the Huddersfield banking company, established 1827

\begin{tabular}{|l|l|l|l|}
\hline Brooke & William & Honley, Yorkshire & Esquire \\
\hline Battye & William & Huddersfield & Esquire \\
\hline Brooke & Joseph & Huddersfield & Merchant \\
\hline Smith & John & Huddersfield & Merchant \\
\hline Armitage & Joseph & $\begin{array}{l}\text { Milnsbridge House, } \\
\text { Yorkshire }\end{array}$ & Wool Manufacturer \\
\hline Walker & Joseph & $\begin{array}{l}\text { Lascelles Hall, } \\
\text { Kirkheaton, }\end{array}$ & Yorkshire \\
\hline Allen & $\begin{array}{l}\text { Benjamin } \\
\text { Haigh }\end{array}$ & Huddersfield & Esquire \\
\hline
\end{tabular}

Source: HSBC Group Archives [HSBCGA]: Huddersfield Banking Company [HBC],

Deeds of Settlement, $1^{\text {st }}$ June 1827

The directors of the Huddersfield Banking Company appear to have developed a good relationship with their manager, Mr. Carter, and therefore trusted his judgment on a number of matters. The Huddersfield Banking Company, founded in 1827, was one of the first joint-stock banks to be formed after the 1826 Bank Act. Its first directors, all of who had to own at least 20 shares in the bank, were local men. They were mostly involved in the local industry (see Table 3), although the bank also had local men of independent wealth acting on its board. ${ }^{5}$ In June 1828, the directors 'left to Mr. Carter to grant' George Hampshire’s application for $£ 100$ 'provided he is satisfied with $\mathrm{Mr}$. 
Hampshire's own responsibility'. Likewise, in August of the same year, the directors were happy to lend William Lee a temporary credit of $£ 500$ 'if Carter thinks it perfectly safe'. In other instances, the directors followed their manager's advice. The board consented to a decision to lend $£ 700$ credit without security to William Hallas senior, a cloth manufacturer, at the Wakefield branch, as 'Mr. Carter writes that he is perfectly safe'. ${ }^{6}$ Without their own banking experience, this board relied heavily on the judgement, talent and expertise of their manager.

As shown in the example above, there would have to be some trust, delegation, and authority given to others to decide some matters, otherwise, the board would be overwhelmed and meetings would become convoluted with trivial matters. The exact threshold for board approval of lending levels differed between boards, types of credit and from bank to bank, as the scale of business which took place there would not be the same for each bank or branch. The board of directors' minute books examined here do not explicitly state such thresholds. However, it is possible to discern some of the guidance from the directors in this study by examining the minute books.

Table 4: First Directors of the Nottingham and Nottinghamshire Banking Company, established 1834

\begin{tabular}{|l|l|l|l|}
\hline Unwin & Edward & Sutton In Ashfield & Esquire \\
\hline Percy & Henry & Nottingham & Gentleman \\
\hline Cox & Charles & Wilford & Merchant \\
\hline Wood & Henry Mosses & Nottingham & Architect \\
\hline Hedderley & John & Nottingham & Chemist and Druggist \\
\hline
\end{tabular}

Source: RBSGA: Nottingham and Nottinghamshire Banking Company [NNBC], BDM, 574. 
In contrast to the previous example, the directors in Nottingham and Nottinghamshire Banking Company wished to be involved heavily in the decision-making process. The board adopted a somewhat cautious approach towards delegation. The bank was founded in 1834 with a capital of $£ 500,000$. As Table 4 shows, the directors themselves were men of businesses or independent wealth. All were local. The founding committee of the Nottingham and Nottinghamshire Banking Company declared that particular accounts were 'to be decided by the directors on their respective merits, and the nature of account proposed to be kept' ${ }^{7}$ In 1834 , the Nottingham and Nottinghamshire Bank directors state that: 'the manager and cashier [are] not to advance on bills when ignorant of the parties until one at least of the [Bill] Committee approve. ${ }^{8}$ Thus, the directors did not intend to allow the manager to act alone and instructed that he act through discussion with others, even though he was an experienced banker.

Mr. Watt of Edinburgh served as the manager of the Nottingham and Nottinghamshire Bank. With this appointment, the directors noted that Watt was 'experienced in Scottish joint-stock banks', where such institutions had been operating since the 1770s (Cameron 1967; Checkland 1975; Munn 1980). ${ }^{9}$ Thus, this new bank imported expertise and experience in joint-stock banking from north of the border. Other banks, such as the Sheffield and Rotherham Banking Company, imported talent directly from the private banks.

The Sheffield and Rotherham Banking Company was a conversion of a private bank, Walker, Eyre and Stanley. Converted in 1836, it opened one branch in 1837, and no more until 1856 (Anon 1992). By 1850, it had a paid-up capital of $£ 27,000$ and a reserve fund of $£ 12,000$ (Newton 1996: 67). The region in which the bank was 
located focused on iron, steel, coal and secondary metal trades, and this is reflected in the occupations of the bank's first directors. However, as a private bank conversion, the Sheffield and Rotherham also had three professional bankers on its founding board, who had been partners of the old bank (see Table 5).

Table 5: First Directors of the Sheffield and Rotherham Joint-stock Banking Company, established 1836

\begin{tabular}{|l|l|l|l|}
\hline Creswick & Thomas & Sheffield & Silver plater and cutler \\
\hline Sanderson & John & Sheffield & Merchant \\
\hline Walker & Henry & Rotherham & Banker \\
\hline Walker & Joshua & London & Banker \\
\hline Stanley & Charles & Sheffield & Banker \\
\hline Hounsfield & Bartholomew & Sheffield & Colliery Agent \\
\hline Jackson & Thomas & Rotherham & Unknown \\
\hline
\end{tabular}

Source: RBSGA: Sheffield and Rotherham Banking Company [SRBC], BDM, $\mathrm{SR} / 1 / 1,01095 \mathrm{~S}$.

Tables 5 demonstrate that local men of means represented the shareholding and acted as directors in the new joint-stock banks. Banks such as the Bilston District Banking Company had a board composed of local industrialists. The Sheffield and Rotherham, as a conversion of a private bank, operated with three men who identified themselves as professional bankers. The Liverpool Union Banking Company was a bank established by merchants of Liverpool to service the activity of trade and commerce in this international port. The banks established in Nottingham and Huddersfield possessed boards of directors who were local industrialists but also those who could be described as the 'great and the good' - gentlemen and those with property, either 
landed gentry or wealthy industrialists, who preferred to describe themselves as 'esquire'.

On the whole, bank directors tended to form a part of the local business community. It is also important to note that this was an era in which the restrictions upon communication and travel resulted in a relatively parochial sphere of activity for such men. With the onset of the railway age and later, the telegraph, regional markets would integrate. Yet, in the 1820 s and 1830 s, with a postal service that relied upon canals, waterways, and horses, markets were separated and seldom interacted. As bank directors originated from a relatively concentrated geographical area which was near to the bank, they were likely to have formal or informal contact with local merchants, as well as knowledge of the local commercial and industrial landscape. They could have had real and practical experience of dealing with those applying for credit. Information about others in the commercial and industrial world around them would be useful in determining the creditworthiness of firms and individuals. This leads us to consider the lending activity which these bank directors oversaw in more detail.

\section{Lending activity}

With the entrance of the joint-stock bank and its new systems of governance and managerial hierarchy, the organisational form of banks had changed. Yet, this did not necessarily translate into a new and different credit market that had become depersonalised or mechanical. This was a different matter. As directors and managers operated jointly (if only ideally), the term 'banker' refers to individuals who were both managers and directors, even if they did not identify as such. This section 
examines lending and related decision-making in more detail. It assesses the level of security or collateral in order to detect the lender's relationship with the borrower.

The request for, and use of, security was most apparent in instances when the loan applicant was considered to be a 'weak' proposition in terms of creditworthiness, as an individual, a firm or for a specific project. Collateral security offered an additional source of revenue in the event of default. More recently, Stiglitz and Weiss $(1983,1981)$ have shown that the provision of security can reduce the likelihood of customers taking risks and so lower the number of unrepayable loans. Although those in the nineteenth century appeared to agree with this idea in principle, it did not seem to be articulated in this exact form.

George Rae, a joint-stock banker, served as an important figure in educating the fellow financiers. He believed that banks should demand security from all applicants. He advised that bankers should '[r]eject... everything that is not readily convertible into money' and to make 'safe' advances; 'never... without security' (Rae 1850: 37). In reality, joint-stock banks did not follow Rae's instructions and insist upon the provision of security for all loans made. For example, when Collins and Capie surveyed bank lending in England between 1860 and 1914, they found that 'somewhere over half of the industrial overdrafts made in the provinces did not involve the formal deposit of securities - they were either wholly unsecured or relied on the signing of personal guarantees' (Capie and Collins 1999: 42; 1996: 35). Even by the twentieth century, 32 percent of a sample of bank loans by English commercial banks (1920-1939) had no collateral security or relied on personal guarantees (Collins and Baker 2003).

Rae himself did not follow his own advice either and he lent without security. Rae became inspector of branches at the North and South Wales Bank in 1839. He 
proceeded to rise in rank to become Managing Director in 1865, a position in which he made lending decisions and enforced policy. Reference to the board of directors' minute books (from the 1830s onwards) of the bank will find many instances of credit granted by this bank on illiquid security or no security at all (Collins and Hudson 1979: 77-8; Crick and Wadsworth 1936: 167-94, 425-35). ${ }^{10}$ Likewise, private country bankers preceding these joint-stock intuitions 'often lent, at least before 1815, without collateral or security of any kind' (Pressnell 1956: 302-3).

While the use of collateral may have a psychological effect on borrowers and their behaviour, lending without security was only risky from the bank's perspective if the applicant could (or would) not repay. Without credit-reporting agencies, bankers themselves investigated the individual in order to establish whether the application had the ability or means to honour the agreement. Thus, it was the task of the directors and the manager to protect the bank's investment and to predict the likelihood of repayment or default on any given application for an advance.

Table 6 shows lending data collected and analysed for the five banks, covering the first three years of their operation. ${ }^{11}$ It reveals the amount of credit that was applied for without the offer of any security in the five banks examined here as well as the approval rating of those applications. It calculates these figures from the entries made in the directors' minute books. It, therefore, does not include any applications which would be rejected prior to this stage in the application process. English jointstock banks lent to their customers through the discounting of bills of exchange and via overdrafts. These tended to be short-term forms of credit, yet the bank based this activity on funds from deposits, which were subject to withdrawal at short notice. Some longer-term lending took place through the roll-over of overdrafts. Our calculations do not include discounts from bills as they would usually be discounted 
by a manager or a clerk. As a result, these numbers would not be entered into the directors' minute books (Gilbart 1828: 44; Nishimura 1971).

In the first half of the nineteenth century, types of security provided were typically property, company works, bonds, shares (especially railway shares from the 1840s), surety and promissory notes. Some of these terms were prevalent in this period and no longer apparent in today's credit market. A promissory note was defined as written promise for the payment of money which transferred in the same way as a bill of exchange (Roscoe 1829: 3). Surety was a contract which permitted another to take responsibility for the performance and repayment of a debt (Theobald 1832: 1-2). Despite such a range in types of security and their liquidity, joint-stock banks regularly extended credit to customers without any kind of security at all. 
Table 6: Assessment of credit applications by five joint-stock banks

\begin{tabular}{|c|c|c|c|c|c|c|c|}
\hline Bank and years & $\begin{array}{l}\text { Total Credit } \\
\text { applied for }\end{array}$ & $\begin{array}{l}\text { Security } \\
\text { offered (\% of } \\
\text { total } \\
\text { applications) }\end{array}$ & $\begin{array}{l}\text { Approval rate (\% } \\
\text { of applications } \\
\text { where security } \\
\text { offered) }\end{array}$ & $\begin{array}{l}\text { Average size of } \\
\text { credit application } \\
\text { where security } \\
\text { offered }\end{array}$ & $\begin{array}{l}\text { No security } \\
\text { offered (\% of } \\
\text { total applications) }\end{array}$ & $\begin{array}{l}\text { Approval rate (\% of } \\
\text { applications where no } \\
\text { security offered) }\end{array}$ & $\begin{array}{l}\text { Average size of credit } \\
\text { application where no } \\
\text { security offered }\end{array}$ \\
\hline $\begin{array}{l}\text { Liverpool Union Banking } \\
\text { Company }(1835,1836 \text {, } \\
1837)\end{array}$ & 336504 & 59.15 & 92.21 & $£ 3055$ & 40.85 & 73.67 & $£ 7108$ \\
\hline $\begin{array}{l}\text { Nottingham and } \\
\text { Nottinghamshire Banking } \\
\text { Company }(1834,1835, \\
1836)\end{array}$ & 181825 & 57.54 & 78.83 & £658 & 42.46 & 71.85 & $£ 813$ \\
\hline $\begin{array}{l}\text { Huddersfield Banking } \\
\text { Company }(1827,1828 \text {, } \\
1829)\end{array}$ & 580821 & 70.71 & 58.95 & $£ 1488$ & 29.29 & 49.54 & $£ 950$ \\
\hline
\end{tabular}

Sources: $\quad$ RBSGA: BDBC, BDM, 11342; NNBC, BDM, 574; SRBC, BDM, SR/1/1, 01095S. HSBCGA: HBC, BDM, H4. LBGA: LUBC, BDM, 93. 
The lending data for early joint-stock banks in Table 6 shows that these five banks extended considerable amounts of credit with no collateral provided to secure it. In the case of four out of five banks in this sample, $40-49$ percent of credit applications had no security offered on them at all. For the other bank in the sample, the level was slightly lower at 29 percent. Such applications had relatively high approval ratings 50-76 percent. Not all applications for credit were without any form of collateral. Table 6 shows that applicants offered security in a significant number of submissions for credit - from 50-70 percent - with a success rate of 59-92 percent, slightly higher than that for applications without any security offered. Therefore, an application for credit with no security offered does not seem to have unduly hindered their chances of success, although an application with security offered was slightly more likely to succeed.

The discussion in this section has shown that bankers subscribed to the view that lending without security was not inherently dangerous and that steps could be taken to reduce the hazards. White's analysis of banking in nineteenth century California revealed that if the president of the Bank of A. Levy (Levy himself) 'determined that an applicant was of good character' he was 'willing to lend large sums with no collateral. But if he decided that a potential borrower's character was flawed, no loan would be offered no matter what collateral' (White 2001: 305-6). This was true relationship banking and it resulted in few losses for the bank in question. The following section turns to the issue of assessing applicants and the steps that bankers took to ensure that when they lent without security, it was safe to do so. 


\section{Assessing creditworthiness}

Frustratingly for the historian, no formal criterion for assessing creditworthiness appears to have been recorded by the joint-stock banks in this period. In his detailed study of private country banks, Pressnell (1956: 292) has emphasised that private 'bankers laid down very little in formal agreements about the conduct of their business. This must be deduced largely from an examination of a multitude of isolated acts of lending... with enrichment from the occasional letter, ledger, or minute-book'. Joint-stock banks were, on the other hand, more organised in record-keeping as they noted decisions about lending in a minute books. Character books became commonplace later in the nineteenth century. While the board minute books rarely provided a full or clear explanation of individual cases, a detailed analysis of the comments made in these sources and the type of security offered does, however, shed further light on the way bankers assessed creditworthiness.

To begin with, a borrower's reputation played a central role. In the language of nineteenth-century bankers, they judged on the grounds of 'respectability' or 'character'. These terms cannot be quantified in any meaningful way as they were both subjective measures. 'Character' could only be assessed through interaction. Bankers, therefore, sought personal knowledge of the applicant and his or her ethical or moral behaviour. And so, banks examined the applicant's tendency to abide by commercial norms. He or she might be recommended by a referee or agent who could speak authoritatively on such matters. Banks, in several examples, used information from other individuals. The Nottingham and Nottinghamshire Bank, for instance, decided that they would only allow Charles Beck a credit of $£ 200$ on his account 'if the references to be found satisfactory'. ${ }^{12}$ 
Although banks had an interest in the applicant as a person, not all assessments made by others were simply about character. Directors also relied on 'hard' information from other banks to ensure that the security offered was valid. In May 1835, the Nottingham and Nottinghamshire Bank Directors accepted a guarantee that had been 'verified by bankers Sparrow and Co of Maldon' in Essex on an advance for $£ 300 .{ }^{13}$ This evidence, apart from providing reassurance, demonstrated the applicant's relationship with another bank in another region. It provided an indirect sign that the borrower had entered into mercantile transactions before and held at least some standing in that part of England.

Associations often communicated social status or position silently, and this would indicate the individual's wealth. In order to hold the quality of 'respectability' and be 'respectable', an individual should hold a solid position or connection to those within the echelons of local commercial society. The more affluent the applicant or qualified the referee, the stronger the request for credit. Joseph Armitage, one of the first directors of the Huddersfield Banking Company, applied for, and was granted, an overdraft of $£ 300$ without security. As a director who represented his fellow shareholders, he evidently stood as a man who had been elevated above his peers. He was known to the bank as a man who possessed both money and property. For instance, Armitage held 30 bank shares worth $£ 300$. The bank was clearly prepared to lend to one of their own. Granting credit without security in this case and to this applicant was a low-risk activity. Indeed, the new joint stock banks lent to their own directors, but such 'insider lending' tended to be undertaken in moderation and tended not to destabilise the banks (Newton 1996: 67, 73-5, and Newton 2010: 40). 
For those who could not find another known to the bank to introduce the applicant or guarantee the debt, it could result in a negative response. If the management or directors did not know the applicant for credit, then they would investigate. The Liverpool Union Bank’s Directors agreed that $£ 500$ could be advanced to John Page and Co. 'if satisfied upon further enquiry'. ${ }^{14}$ Again, in the example of Nottingham and Nottinghamshire Banking Company, the manager was to make enquiries into the 'responsibility' of Benjamin Walker of Nottingham when he applied for an advance of $£ 400$ without security. The enquiries must not have been favourable as his request for credit was declined. ${ }^{15}$

On other occasions, when bankers could not establish the applicant or the guarantor's disposition, they simply abandoned the advance. In 1828, Thomas and Richard Binney, corn dealers from Wakefield, applied for $£ 5,000$ without security. The Huddersfield Bank directors deferred their decision on the basis that 'the Directors not being sufficiently acquainted with the parties' ${ }^{16}$ A polite way to refuse was to seek an indefinite delay. In other instances, directors proved more direct in dismissing applicants. In March 1838, the same directors would not grant $£ 500$ of credit to John Hay of Leeds secured by Richard Hay, also of Leeds (and presumably a relative), requiring another surety 'as the parties are strangers to the directors.' 17

If a bank was uncertain as to the creditworthiness and trustworthiness of a company or an individual, they could apply caution and monitor the operation of their bank account over a longer period. The Liverpool Union Banking Company employed this strategy. It permitted Robert Wise and Co. to open an account with the newly formed bank in 1835 but advised: 'caution recommended regarding this house and no advance be given'. ${ }^{18}$ The account would provide a record of income as well as 
interactions with the individual. The same bank offered George Law an account with credit but clearly wished to monitor his activity, stating that:

'Advance to be made (if required) to the extent of $£ 1,000$ to George Law Junior for the present and to be extended to $£ 2,000$ at a future time if the account should appear to be safe, and otherwise profitable for the bank.' 19 Thus, repeated transactions allowed the bank to build up a view of the applicant and provided further information on which to base lending decisions on. The longer the relationship between bank and customer, the more information about the customer was gathered and a better assessment of their creditworthiness could be made (Galassi 1996).

It was in the interests of the borrower to repay on time and behave within the rules specified by bank directors, as this could lead to access to further credit in the future. In contrast, failure to repay or abide by the rules laid down by directors would be likely to make it more difficult to obtain credit on the next request. This links to the work of Axelrod (1984), who emphasises the importance of the 'shadow of the future' in economic transactions, whereby opportunist behaviour one day could lead to negative consequences for the malefactor in the future.

Personal wealth, such as ownership of substantive property and/or investments, as well as a successful business, mattered in assessing the creditworthiness of customers. This was especially apparent in the case of those borrowing and offering personal security or the guarantee of another to secure the repayment of the debt. The firm of Lockwood and Cockburn, cloth manufacturers, applied for credit on their Huddersfield bank account of $£ 2,000$ on the security of a joint and personal bond with Abraham and Thomas Lockwood (two of the bank's original directors) of $£ 2,000$. When issuing the approval, the directors noted that firm 
had an income of $£ 15-20,000$ per annum. It indicated that the business was profitable and it had generated custom for the bank on its account and was able to pay back the money. ${ }^{20}$ The bank directors' personal bond, as well as good returns on a company's account, would appear to make this a low-risk advance.

Despite the importance of relationships, being known or having a good referee was not a recipe for success. For individuals who were known but not 'respectable' enough or lacked good 'character', collateral security was needed. Dunning and Hemmings of Bilston, for instance, were permitted to borrow $£ 88$ on their own security. Yet, for a larger sum, the directors confirmed that formal security, such as deeds or shares, needed to be provided. ${ }^{21}$

Overall, decisions to lend were inconsistent and often appear to be based on the individual themselves and their reputation. The possession of a 'respectable' social position, wealth and the subsequent ability to inspire confidence was especially important in assessing creditworthiness. Assessments took the form of informal, personal character-based evaluations. Banks screened applicants in order to avoid lending to those with undesirable reputations or who could not repay. An applicant increased the possibility of acquiring credit by providing clear indicators that they (or another) could and would repay. Bankers acquired information on borrowers through the support, advice and recommendation of those within the local business network or fellow bankers. On receipt of positive responses, joint-stock banks felt confident enough to lend large sums even without any form of collateral security. 


\section{Conclusion}

When he wrote about the distinction between private and joint-stock bank, Henry Withers (1910), a financial journalist, commented that:

'Any differences that exist between the private and joint-stock banks of England lie in their ownership rather than in their functions. Their functions are the same, but the manner in which they carry them out is perhaps influenced to a slight extent by the fact, which really distinguishes them, that the private banks are owned by a few partners who generally conduct the business for themselves or exert more or less influence on it, while the joint-stock banks are managed by salaried directors and officials on behalf of a large body of shareholders formed into a public company, the shares in which can as a rule be bought and sold on the London Stock Exchange'.

This vision was, for the most part, as true in 1910 as it was in the first half of the early nineteenth century. Indeed, we find that with the entrance of the joint-stock bank, a clear change took place in the form of banking and its appearance. The vast majority of joint-stock banks were not understood or marketed through the personalities or characteristics of their owners. Most had too many owners for this to be achieved in the same way that it had worked for the private banks. Despite this, the new organisational form remained tied to its human owners. Without the powers of incorporation, limited liability, and the separate corporate entity, the joint-stock bank could not become a personality in itself. The bank's identity was fused with the large 
group or swollen body of owners who underwrote the firm's debts in the event of failure.

Even so, the early joint-stock bank was not quite yet the public company that Wither's described in 1910 nor was the organisational form the same as a private bank either. The introduction of professional managers and tiered decision-making compared with the relative inactivity of owners meant that the organisation took on a new form. Bank directors in the first half of the nineteenth century were not the salaried professional managers that they would be a century later. Directors during this period were shareholders with greater powers to inspect and challenge rather than operating with the commitment of a full-time or all-consuming position. They assumed a role in monitoring and consulting professional bankers rather than managing the firm itself.

Our analysis of lending activity shows that the changes in organisational form did not result in changes in the style of lending. Private banks lent to customers based on the assessment of personal characteristics and their trustworthiness. The business and mechanics of lending by joint-stock banks remained remarkably similar. Jointstock banks experienced changes in management, ownership, and other presentational nuances, yet they had much in common with their private predecessors when it came to the business of lending. In their financial activity and assessment of borrowers, joint-stock banks relied upon personal connections, local knowledge, and social relationships to establish the reputation and trustworthiness of their applicants, just as private banks did.

Banker managers, directors, and decision-makers were embedded within the community and used contacts to gather intelligence. With good access to information about credit applicants, banks offered high levels of advances without collateral as 
they appeared confident of the debtor's commitment and ability to repay. Applicants who were not well-known in local society struggled to access credit without security. Thus, the movement towards depersonalised, disconnected and formalised lending activity did not occur in the first half of the nineteenth century in English banking, even with the entrance of a quasi-corporate entity.

\section{References}

Bank archives

Lloyds Bank Group Archives

HSBC Group Archives

RBS Group Archives

\section{Printed sources}

Anon, 1992. Sheffield \& Rotherham Bank: A banking bicentenary, 1792-1992.

Privately published by The Royal Bank of Scotland, Edinburgh.

Axelrod, R. 1984. Evolution of Cooperation, First edition. New York: Basic Books.

Black, I.S. 2003. 'Private Banking in London's West End, 1750-1830', Lond. J. 28, 29-59. doi:10.1179/ldn.2003.28.1.29

Black, I.S. 1996. 'Symbolic capital: the London and Westminster Bank headquarters, 1836-38', Landsc. Res. 21, 55-72. doi:10.1080/01426399608706475

Cameron, R.E. 1967. 'Scotland', in: R.E. Cameron, ed., Banking in the Early Stages of Industrialization: A Study in Comparative Economic History. Oxford: Oxford University Press. 60-99. 
Capie, F. and M. Collins. 1999. 'Banks, Industry and Finance, 1880-1914', Bus. Hist. 41, 37-62. doi:10.1080/00076799900000201

Capie, F. and M. Collins. 1996. 'Industrial Lending by English Commercial Banks, 1860s-1914: Why Did Banks Refuse Loans?', Bus. Hist. 38, 26-44. doi:10.1080/00076799600000002

Checkland, S.G. 1975. Scottish banking: a history, 1695-1973. Glasgow: Collins. Collins, M. 1994. 'The growth of the firm in the domestic banking sector', in: M.W. Kirby and M.B. Rose, eds., Business Enterprise in Modern Britain: From the Eighteenth to the Twentieth Century. London: Routledge, 263-286.

Collins, M. and M. Baker. 2003. Commercial Banks and Industrial Finance in England and Wales, 1860-1913. Oxford: Oxford University Press.

Collins, M. and P. Hudson. 1979. 'Provincial Bank Lending: Yorkshire and Merseyside, 1826-601', Bull. Econ. Res. 31, 69-79. doi:10.1111/j.14678586.1979.tb00143.x

Cottrell, P.L. 1980. Industrial Finance, 1830-1914: The Finance and Organization of English Manufacturing Industry. London: Methuen.

Crick, W.F. and J.E. Wadsworth. 1936. A Hundred Years of Joint Stock Banking.London: Hodder \& Stoughton.

Dawes, M. and C.N. Ward-Perkins. 2000. Country Banks of England and Wales: Private Provincial Banks and Bankers, 1688-1953.Canterbury: Chartered Institute of Bankers.

Deakin, S. and F. Wilkinson. 2005. The Law of the Labour Market: Industrialization, Employment, and Legal Evolution, 1st edition. Oxford; New York: Oxford University Press. 
Galassi, F.L. 1996. 'Screening, Monitoring and Incentives in Co-operative Banks: the case of Italy's Casse Rurali, 1883-1926', Univ. Leic. Discuss. Pap. Econ. Soc. Hist. No. ESH962.

Gilbart, J.W. 1828. A Practical Treatise on Banking: Containing an Account of the London and Country Banks, Exhibiting Their System of Book-keeping, the Terms in which They Transact Business, Their Customs in Regard to the Bills of Exchange, and Their Method of Making Calculations : Also a View of Joint Stock Banks, and the Branch Banks of the Bank of England, Likewise Ample Information Respecting the Banks of Scotland and Ireland: with a Summary of the Evidence Delivered Before the Parliamentary Committees, Relative to the Suppression of Notes Under Five Pounds in Those Countries. London: E. Wilson.

Gower, L.C.B. 1979. Gower's Principles of Modern Company Law, 4th edition. London: Stevens and Sons.

Gower, L.C.B. 1953. 'The English Private Company', Law Contemp. Probl. 18, 53545. doi:10.2307/1190461

Grossman, R.S. 2010. Unsettled Account: The Evolution of Banking in the Industrialized World since 1800. Princeton: Princeton University Press.

Harris, R. 2000. Industrializing English Law: Entrepreneurship and Business Organization, 1720-1844. Cambridge, UK; New York: Cambridge University Press. Ireland, P. 1996. 'Capitalism without the capitalist: The joint stock company share and the emergence of the modern doctrine of separate corporate personality', J. Leg. Hist. 17, 41-73. doi:10.1080/01440369608531144

Michie, R.C. 1981. Money, Mania and Markets: Investment, Company Formation and the Stock Exchange in Nineteenth-century Scotland. Edinburgh:. J. Donald Publishers. 
Munn, C.W. 1980. Scottish Provincial Banking Companies, 1747-1864. 1st edition.

Edinburgh: John Donald Publishers Ltd.

Newton, L. 1996. 'Regional Bank-Industry Relations during the Mid-Nineteenth

Century: Links between Bankers and Manufacturing in Sheffield, c.1850 to c.1885',

Bus. Hist. 38, 64-83. doi:10.1080/00076799600000095

Newton, L. 1997. 'Towards Financial Integration: the Development of English Joint

Stock Banks in London and the Provinces', in: U. Olsson, ed., Business and European

Integration since 1800: Regional, National, and International Perspectives.

Göteborg: Göteborg Universitet. 316-331.

Newton, L.A. 2010. 'The birth of joint-stock banking: a comparison of England and

New England in the nineteenth century', Business History Review 84: 1, 27-52.

Nishimura, S. 1971. The Decline of Inland Bills of Exchange in the London Money

Market, 1855-1913. Cambridge: Cambridge University Press.

Orbell, J. and A. Turton. 2001. British Banking: A Guide to Historical Records.

Aldershot: Ashgate.

Pearson, R. 2004. Insuring the Industrial Revolution: Fire Insurance in Great Britain, 1700-1850. Aldershot, Hants, England; Burlington, VT: Ashgate Pub Ltd.

Pressnell, L.S. 1956. Country Banking in the Industrial Revolution. Clarendon Press.

Rae, G. 1850. The internal management of a country bank: in a Series of Letters on the Functions and Duties of a Branch Manager. London: R. Groombridge \& Sons.

Roscoe, H. 1829. A Digest of the Law Relating to Bills of Exchange, Promissory

Notes, and Bankers' Checks: With an Appendix Containing the Statutes and Forms.

London: Saunders and Benning.

Sayers, R.S. 1957. Lloyds Bank in the history of English banking. Oxford: Clarendon Press. 
Stiglitz, J.E. and A. Weiss. 1981. 'Credit Rationing in Markets with Imperfect Information', Am. Econ. Rev. 71, 393-410.

Stiglitz, J.E. and A. Weiss. 1983. 'Incentive Effects of Terminations: Applications to the Credit and Labor Markets', Am. Econ. Rev. 73, 912-27.

Theobald, W. 1832. A Practical Treatise on the Law of Principal and Surety, particularly with relation to mercantile guarantees, bills of exchange, and bail bonds. Turner, J.D. 2009a. 'Wider share ownership?: investors in English and Welsh Bank shares in the nineteenth century', Econ. Hist. Rev. 62, 167-92. doi:10.1111/j.14680289.2009.00477.x

Turner, J.D. 2009b. “"The last acre and sixpence”: views on bank liability regimes in nineteenth-century Britain', Financ. Hist. Rev. 16, 111-27. doi:10.1017/S0968565009990047

Turner, J.D. 2014. Banking in Crisis: The Rise and Fall of British Banking Stability, 1800 to the Present. Cambridge: Cambridge University Press.

White, E.N. 2001. 'California Banking in the Nineteenth Century: The Art and Method of the Bank of A. Levy', Bus. Hist. Rev. 75, 297-324. doi:10.2307/3116647 Wordsworth, C.F.F. 1842. The Law of Joint Stock Companies. London: Saunders and Benning.

\footnotetext{
${ }^{1}$ We would like to thank the archivists at RBS Group Archives, HSBC Group Archives and Lloyds Bank Group Archives for their generous help in researching this work. We would also like to thank those who commented on the initial draft of this chapter at the international workshop, 'The Other Side of Banking: Non-institutional credit across Europe (18th-20th cc.)' in June 2015 at the University of Trento. This research was supported by a funding from the Economic and Social Research Council [grant number ES/J500148/1].
} 
${ }^{2}$ LBGA: LUBC, BDM, Book no. 093, 2 Feb. 1837.

${ }^{3}$ LBGA: LUBC, BDM, Book no. 093, 2 Feb. 1837.

${ }^{4}$ LBGA: LUBC, BDM, 093, 21 Aug. 1837.

${ }^{5}$ HSBCGA: HBC, BDM, H4, 21 Jan. 1827.

${ }^{6}$ HSBCGA: HBC, BDM, H4, 13 June 1828 and15 Aug. 1828.

${ }^{7}$ RBSGA: NNBC, BDM, 574, 7 Apr. 1834.

${ }^{8}$ RBSGA: NNBC, BDM, 7 Nov. 1834.

${ }^{9}$ RBSGA: NNBC, BDM, 574, 4 Mar. 1834 and 4 Apr. 1834.

${ }^{10}$ HSBCGA, BDM, North and South Wales Bank.

${ }^{11}$ Given the density of the data it has been necessary to take sample years. All lending decisions that went before the board in these years have been analysed.

${ }^{12}$ RBSGA: NNBC, BDM, 574, 18 Apr. 1834.

${ }^{13}$ RBSGA: NNBC, BDM, 574, 8 May 1835. Sparrow and Co. were private bankers in Essex. See Orbell and Turton (2001: 487) and Dawes and Ward Perkins (2000: 147-8).

${ }^{14}$ LBGA: LUBC, BDM, Book no. 093, 1 October 1835.

${ }^{15}$ RBSGA: NNBC, BDM, 574, 3 Apr. 1835.

${ }^{16}$ HSBCGA: HBC, H4, BDM, 11 Jan. 1828.

${ }^{17}$ HSBCGA: HBC, H4, BDM, 7 Mar. 1828.

${ }^{18}$ LBGA: LUBC, BDM, Book no. 093, 4 June 1835.

${ }^{19}$ LBGA: LUBC, BDM, Book no. 093, 3 Sept. 1835.

${ }^{20}$ HSBCGA: HBC, H4, BDM, 23 Aug. 1827.

${ }^{21}$ RBSA: BDBC, BDM, 11342, 12 June 1838. 